\title{
Goldman Environmental Prizes
}

The Goldman Environmental Prizes comprise the world's largest environmental prize programme, as they provide annually US $\$ 60,000$ to an outstanding environmentalist from each of the six inhabited continents. To the best of our knowledge there are no other major awards which recognize outstanding achievement from each of the inhabited continents in any such manner. This not only illustrates that environmental work on any one continent is likely to be as important as environmental work on any other continent, but it also implies that environmental problems are very much interrelated.

The six awards are presented annually to outstanding 'grassroots' environmentalists, which announcement emphasizes that this is not an award for scientific or academic achievement, nor is it an award that will primarily go to those who are already noted in their field.* The following brief descriptions of our first-year winners illustrate this point quite well.

Africa:- Michael Werikhe, widely known as the 'Rhino Man', is a security supervisor at an automobile assembly plant in Kenya who has walked across Africa and Europe to raise funds and public awareness to help save the Black Rhinoceros (Diceros bicornis).

Asia:- Harrison Ngau is a member of the Kayan community of Sarawak, the Malaysian state on Borneo. He has been jailed and placed under house arrest for his effort to prevent the logging of the Malaysian rain-forest.

Australia:- Dr Robert Brown, of Tasmania, gave up his medical practice to devote his full time to help save the Franklin River, which was threatened by an unnecessary dam. Not only was the dam project stopped but, as a result in part of Dr Brown's efforts, preservation of the environment became a popular issue in Australia.

Europe:- Janos Vargha led the successful battle to prevent the Gabcikovo-Nagyamaros dam which was

* Instead it is a major - surely to be warmly applauded attempt to persuade the 'other ranks' and general public throughout the world to do their utmost, at least locally, to safeguard some significant feature or component of our beleaguered world. - Ed. planned for the Hungarian portion of the Danube.

Latin America:- Janet Gibson, working as a volunteer, led the successful effort to have the government of Belize establish the first marine sanctuary (the Hol Chan Reserve) in all of Central America.

North America:- Lois Gibbs, a housewife in the United States, led community efforts resulting in the evacuation of 800 families living next to 22,000 tons of toxic waste in Love Canal, New York.

Nominations for a Goldman Prize can come from either of two sources. The first is a consortium of 18 internationally known environmental organizations. These include such large organizations as the World Conservation Union (IUCN), the United States National Geographic Society, and such small, yet effective, organizations as the Rainforest Action Network and the International Rivers Network. Nominations can also come from any one of 36 invited but anonymous nominators who are based practically throughout the world. Final selections of the winners is made by a jury which includes several prominent environmentalists.

The first Goldman Prize ceremony was held on 16 April 1990 in Herbst Theatre in San Francisco, the site of the signing of the United Nations Charter. The six winners were then flown to Washington, DC, to meet with US President George Bush, who said: 'The Goldman Prizes will recognize ordinary people in six continents who have gone to extraordinary lengths to protect the planet we all share - not because the law demands it, but because they hold a personal environmental ethic which recognizes a responsibility to ourselves, our neighbours, and our children.'.

DUANE SILVERSTEIN, Executive Director
Goldman Environmental Foundation
1160 Battery Street
San Francisco
California 94111
USA.

DuANe Sil verstein, Executive Director

1160 Battery Street

California 94111

USA.

\section{The World Conservation Monitoring Centre (WCMC): What it Is and What it Does}

With the steady increase in pressure upon natural resources, especially in developing countries, the need has never been greater for reliable up-to-date conservation data to promote enlightened development and landuse decisions. Recognizing this need, the three partners in the World Conservation Strategy - IUCN, WWF, and UNEP - have signed an Agreement for the future development of the IUCN Conservation Monitoring Centre. This Agreement pledges the three organizations to the restructuring of the Centre, so that it can effectively fulfil its role as the central repository of data on the world's biological diversity and allied features. Renamed the World Conservation Monitoring Centre (WCMC), the new Centre is registered in the UK as a company limited by guarantee, and has been approved for tax-exempt charitable status. Executive authority for the WCMC programme, budget, and strategic development, is vested in a Management Board comprising two representatives of each partner, although the staff will remain IUCN employees seconded to WCMC.
The mission of WCMC is to support international programmes for conservation and sustainable development through the provision of reliable scientific data particularly on the world's biological diversity. Under the new partnership, the level of core funding provided by IUCN will be equally matched individually by both WWF and UNEP: this will enable the Centre to commence the systematic review and updating of its data, to redesign its databases to meet the evolving needs of its information-users, and to incorporate the recent advances in information technology. This major programme of restructuring will greatly enhance the data-handling capabilities of the Centre, resulting in a greater diversity and flexibility of integrated information outputs to meet the changing needs of the conservation and development community.

To cover the world's biological diversity, WCMC is developing an integrated relational database covering the following major themes:

- data on plant and animal species* of conservation value, including threatened species,* medicinal and 
economic species, ${ }^{*}$ and species* of importance to sustainable development;

- data on the status and distribution of habitats of conservation concern and sites of high biological diversity within these habitats;

- data on the world's protected areas, the main species and habitats which they contain, and the type and effectiveness of the protection that they afford;

- data on the utilization of wild species, and on the patterns and volume of the international trade in wild species and their derivative products; and

- a conservation bibliography to provide references to support these database themes.

Output from this database provide usable information to support the international programmes of the partner organizations and the wider conservation and development community. Primary users are the multinational and bilateral development agencies, government environmental institutes, and non-governmental conservation organizations, as well as multinational corporations and the industrial sector, journalists and television programme makers, university and research institutes, schools, scientists, and individuals involved in conservation work. Particular attention is given to provide the data support needed for the effective operation of all the major international conservation conventions and programmes, including CITES, the World Heritage Convention, the Man and the Biosphere Programme, Ramsar, the International Timber Trade Organization, the Bern Convention, and others.

* As used here, the term species evidently covers also lower taxa. Ed.
WCMC has a policy of charging users who can afford to pay for its information services at a competitive market rate to support the maintenance of its database, although much of its data capture depends upon the free two-way exchange of information.

Most decisions influencing conservation are taken at the national or local level, and WCMC is committed to the establishment of National Conservation Data Centres in developing countries as a priority for improving the availability of information to support national conservation and development projects.

Through its outreach programme, the Centre is also establishing links with other sectoral or geographicallyrestricted databases that are active in the field of biological diversity, to develop a distributed information network. This programme necessitates the development and active promotion of standard terminologies, classification systems, and data transfer formats, to encourage information exchange between database agencies.

This is an ambitious programme. WCMC has the commitment, the necessary expertise, and, through the partnership it now has, the core funding to do the job. However, it still looks to the wider scientific and conservation community as the source of the data, for mutually beneficial data exchange, and for guidance and support in carrying this programme forward.

RoBIN A. PELLEW, Director
World Conservation Monitoring Centre
1219 c Huntingdon Road
Cambridge CB3 ODL
England
UK.

\section{Bridging the Gap Between Theory and Practice: A Systematic Programme of Global Education}

How inspiring it is to read of conferences which present the future for humanity as one of great hope and infinite possibilities, of new relationships among people and with Nature, of a caring and compassionate world, and so many other valuable initiatives! However, at the same time, I read such reports also with a profound sadness. Below, I try to explain why.

The visions of a better world, the light and hope experienced by the participants of conferences are not, for the most part, reaching the great masses of people - the many millions of men and women beyond the conference halls, beyond the newsletters and journals, and beyond the visions and hopes. Certainly there are more and more conferences dedicated to the future of humanity, and there is no question that these are helpful for sharing ideas among visionaries, futurists, and men and women of goodwill; but what about the rest of the people housewives, professional drivers, postmen, local public employees, factory workers - to mention just a few of that great entity comprising 'humanity'? If indeed the challenge to create a better world faces humanity, then surely it is humanity which needs to learn of the hopes, the dreams, and the visions that are apt to be described so eloquently.

The above-mentioned visions are but part of a wider store of riches to which the people at large are entitled. There is a vast wealth at the heart of our planet - an accumulated treasure of wisdom, comprising the perceptions and thoughts of men and women of science and philosophy - a wealth of spiritual and intellectual wisdom. This wisdom is the rightful heritage of all people, and is the basis for the effective use of human consciousness - for the awakening of global ethics and universal common human values. This wisdom, effectively and creatively shared with humanity, can stimulate change in human attitudes and motivate constructive change in human behaviour. Is this not what is needed to create a more humane world?

\section{Duty of Leaders}

Is it not part of the inherent responsibility of thinking people, of people of goodwill and vision, and of leaders of social organizations, to ensure that this wealth is made understandable and accessible to all people everywhere in the world, so that they are informed, awakened, and sensitized to their role in creating a better future?

If the wisdom of visionaries, futurists, and men and women of goodwill, is pictured as a 'cloud' (i.e. the theory of a better future), a large 'gap' exists between this cloud and the consciousness of the many millions of people whose energy and practical cooperation is a prerequisite to the implementation of the theory of an improved future. For the vision to be actualized, the 'gap' must be bridged.

Conferences alone, no matter how frequent and individually impressive, or even if given coverage by television satellites, are not adequate to enhance public awareness, world-wide, of global consciousness and universal values of human responsibility. There is a tendency for the 'good news' - including encouraging visions of the future - to be shared among the 'converted'; but it is 